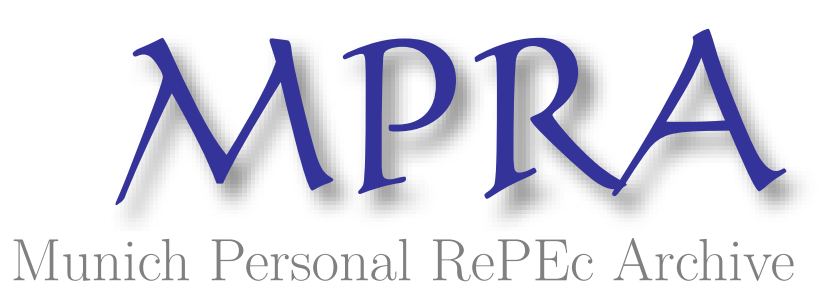

\title{
Philippines and Indonesia: On the way to a migration transition
}

\author{
Amjad, Rashid
}

1 June 1996

Online at https://mpra.ub.uni-muenchen.de/35470/

MPRA Paper No. 35470, posted 20 Dec 2011 05:49 UTC 


\title{
Philippines and Indonesia: On the Way to a Migration Transition
}

\author{
Dr. Rashid Amjad
}

ILO/SEAPAT

This paper, in a comparative analysis of the Philippines and Indonesia, examines first under what conditions can migration favorably contribute to the process of economic development and then to what extent can economic growth impact upon reducing emigration pressures in these labor surplus economies. The paper also argues that there is still considerable scope for putting in place and agreed set of rules and policies to ensure better protection for the more vulnerable migrants.

The dramatic upsurge of overseas migration from many Asian countries to the Middle East during the late 1970s and early 1980s focused attention of policymakers and researchers on its impact, in particular on the domestic labor market, as well as more generally on the overall development process in the labor sending countries. An important issue which was examined in some detail, including by the ILO, was how this phenomenon, especially the large inflows of remittances by overseas workers, could be analyzed within a macroeconomic perspective so that its impact on the economy and the society as a whole could be evaluated. The aim was to develop appro-priate policies and strategies which could help, maximize its development benefits for both the migrant and the sending country and minimize to the extent possible its adverse effects on the economy.

Almost two decades later after these dramatic movements first surfaced, attention seems to haveshifted, motivated perhaps more by the concerns of the labor-receiving countries, to how an acceleration of the process of development in the labor-sending countries could slow down the magnitude of outflow of migrants from these countries. Couched in terms of "emigration pressures," "turning points" and "migration transition," these analytical 
studies focus on factors which would ultimately slow down the pace of outmigration by accelerating the process of economic developmentand job creation in the labor-sending countries so as to reduce the urge or pressure of the domestic labor force to find jobs outside the national boundaries. Again, analysts and researchers (including the ILO) have been recently involved in developing a framework and studying specific country experiences, including in the Asian region, to be able to identify macroeconomic and sectoral policies which would reduce the "emigration pressures" from the laborsending countries.

Besides the well known concern of labor-receiving countries, especially the more developed, about the inflow of migrant workers, there has been also a discernible change in the attitudes of many governments of the Asian laborsending countries, from one of actively and in some cases aggressively encouraging overseas migration to one of reducing the economies dependence on overseas migration. In some cases, this is proposed to be done through outright banning or targeting significant reduction in the number of those leaving the country for employment overseas. This change has been brought about by increasing evidence and growing public feeling in the laborsending countries that migrants, especially females, suffer from considerable exploitation in the labor-receiving countries, and that authorities in these countries have been negligent, or at least very reluctant, to provide adequate protection to their migrant population.

Although an important factor, this has not been the only reason for this change in attitude. There is also at the same time an increasing feeling that the migration phenomenon has not in any real way contributed to the overall development effort in the labor-sending countries. In some cases, its impact may in fact have been more negative than positive, delaying or providing the cushion to procrastinate importantly needed economic and structural reforms in the country.

This important change in public thinking and policy perspective on migration is best illustrated by the example of the Philippines, where especially after the recent hanging in March 1995 of a maid in Singapore, there has been a period of "intense soul searching by the Philippine nation on its status as one of the leading exporters of labor in the world" (Saith, 1996, p.1). In Indonesia too, recent government pronouncements have also indicated a marked preference for shifting overseas migration to the export of skilled labor and away from the large number of female domestic helpers, although the Government would still wish to target a manifold increase in its total remittance flows.

This paper is based primarily on the results of two recent studies conducted by the ILO/SEAPAT (with UNDP financial support) on the Philippines (Saith, 1996) and Indonesia (Nayyar, 1996), which examine the issue of 
emigration pressures and structural change in these countries, as well as a more generalstudy to develop a methodological framework of analysis for the country studies (Connell, 1996). Two other countries, namely Vietnam and China, are also being covered under this project by the ILO's East Asia Multidisciplinary Team (ILO/EASMAT), based in Bangkok. It is expected that these four country reports would identify economic policy issues which have direct or indirect implications for emigration pressures in the short and long term. The effort at this stage is essentially exploratory and is meant to raise issues rather than draw firm conclusions. Each country report, it is hoped, would be able to identify and describe economic policies where a prima facie case can be made of an impact on emigration pressures, and suggesthow these might be taken into account by national authorities in designing development strategies.

The primary focus of this paper is to examine two central issues which havedominated the development debate on migration. The first is on the nexus between development and migration or more pertinently in what way, if any, and under what conditions can migration favorably contribute to the process of economic development. The second is the extent to which higher rates of economic growth and more employment-intensive development can impact upon reducing emigration pressures in a predominantly labor surplus economy.

Clearly, these are complex and wide issues and defy easy answers. But it is hoped that an analysis of the development and migration experience of the two countries covered in this paper could assist us in formulating our views on these difficult questions. The experience of these two countries may be especially pertinent as one of the two countries being examined, namely the Philippines, is commonly referred to as the second largest global exporter of labor, while at the same time, its development experience over the last two decades has been, at least until very recently, extremely disappointing. On the other hand, Indonesia is now cited as one of the "East Asian Miracle" countries with an extremely impressive economic performance over the last two and half decades, and yet overseas migration, though not insignificant, has been somewhat marginal in its overall impact on economic development in the country.

The central message of this paper still remains essentially unchanged from the position taken by the author in his earlier analysis (Amjad, 1989), that migration can have an overall favorably impact on the development process through the adoption of conducive overall macroeconomic and sectoral policies and selective policy interventions by the Governments in the laborsending countries. Not surprisingly, it is also the same policy package which would move the labor-sending country towards the so called "turning point" in the migration process by accelerating the process of development and productive job creation in the domestic economy. 
The paper does not examine in any great detail the demand prospects for migrantlabor in the labor-receiving countries. Nor does it examine the impact of inflow of migrant labor on the host country either in terms of economic benefits or social costs. However, the underlying argument is, and this is only briefly elaborated upon in different parts of the paper, that there is still considerable scope for putting in place an agreed set of rules and policies which could lead to economic and social benefits for both the labor-sending and labor-receiving countries, and at the same time, ensure better protection for the more vulnerable migrants. At a time when xenophobic sentiments seem to be fast gaining ground in many industrialized and semi-industrialized economies, and also in labor-receiving developing countries, this view may been seen as somewhat "optimistic." However, the age-old phenomenon of emigration has been threatened before, and in an increasingly globalized world the chances that it will drastically slow down or abruptly come to an end are at the very least remote. It is, however, especially important at the present time to openly debate the merits and demerits of migration and examine policies which will make it mutually beneficial for both laborsending and labor-receiving countries and help resolve the highly emotive and charged debate on this issue.

\section{Economic Experience of the Philippines and Indonesia}

It may be best to recount, albeit briefly, the main features of economic development that the Philippines and Indonesia have experienced during the last thirty years.

In the Philippines, average living standards steadily declined over the last three decades relative to its neighbors in East and South-East Asia. According to Khan (1996), in 1960, the Philippines had a real per capita GDP (purchasing power parity \$GDP) which was higher than that of Indonesia, Thailand, Republic of Korea, Taiwan/Province of China (hereafter referred to as Taiwan/China) and the People's Republic of China. By the early 1990s, it had fallen below all these countries. As compared to the Republic of Korea, its per capita real GDP was 28 percent higher in 1960, but by the early 1990s, it had become 71 percent lower. It is important to note that even in absolute terms per capita GDP in the Philippines was lower in 1991 as compared to 1977.

A breakdown of Philippines growth performance shows that it performed moderately well during the 1960 s and 1970 s, but dismally during the 1980 s and the early 1990s. During the earlier period, it achieved a 6 percent annual rate of growth in GDP (3 percent in percapita GDP), which though much lower than most of its East Asian neighbors was significantly higher than those of the less developed countries taken as a whole. However, even during this 
period, its success in reducing the incidence of poverty was very limited in absolute terms and distinctly poor in comparison with what was achieved by its neighbors. An important factor was the inadequate expansion of productive and remunerative employment which still remains as the most effective means of reducing poverty.

During the subsequent period 1980-1993, per capita GDP fell at an average annual rate of 0.5 percent per year. The most dramatic decline was during 1983-1985 when growth fell by 15 percent. Despite some decline in the level of poverty from 49.3 percent during $1983-1985$ to 41.3 percent in $1992-$ 1994 (Balisacan, 1996), the absolute level of poverty remains extremely high, at a time when many of its neighbors in East and Southeast Asia have achieved remarkable success in reducing poverty. The country has not improved its performance in terms of most human development indicators. While significant improvements were registered in measures of health and education through the 1960 s and 1970 s, progress has drastically slowed down in the subsequent period. Infant mortality declined very little, especially from the late 1970s to the mid-1980s from 66 per 1,000 live births in 1970 to 48 in 1992. More than a quarter of the population was functionally illiterate, although the 1990 census reported a 94 percent literacy rate (see World Bank, 1995a). Unfortunately, political developments and resulting uncertainty, natural disasters, the debt crisis and subsequent forced stabilization, all contributed to this dramatic decline.

Over the last two years, political stability and the institution of economic reforms have led to a revival of economic growth. During 1994, economic growth was 5.5 percent, in 1995 nearer 6 percent and is estimated to reach 7 percent in 1996. However, the growth momentum still remains fragile and its employment impact is still to be fully realized.

In sharp contrast to the Philippines, the development experience of Indonesia during the last twenty-five years is extremely impressive, and in some key respects comes close to the successful experiences of East Asian countries. During this period, per capita income increased at a rate of 4.5 percent per annum while the growth in GDP was almost7 percent per annum. As Nayyar (1996) points out, there were also major improvements in indicators of human development as life expectancy rose from 45.7 years in 1970 to 61.5 years in 1990, infant mortality fell from 145 per thousand in 1970 to 68 per thousand in 1990 and adult literacy rates increased from 54 percent in 1970 to 82 percent in 1990 . Between 1960 and 1990, the crude birth rate declined from 44 per thousand to 28 per thousand, the crude death rate dropped from 23 per thousand to 9 per thousand, and the under-five mortality rate fell from 225 per thousand to 97 per thousand.

The high rates of economic growth, especially the spectacular growth in labor-intensive manufactured exports (which increased from US $\$ 800$ million 
in 1985 to almost US $\$ 7,000$ million in 1991), have been "employmentfriendly" and have led to an appreciable decline in poverty levels. The percentage of people living below the poverty line is estimated to have declined from 40 percent in 1976 to 17 percent in 1992 . While the reduction in the incidence of poverty was about the same in rural and urban areas, there are, however, large regional variations which are closely linked to the level of development within a region.

It must, however, be emphasized that despite its impressive overall economic performance Indonesian has only recently graduated from a lowincome to a lower middle-income economy with a per capita income in 1993 of US\$ 740 (World Bank, 1995b) and its real GDP per capita based on purchasing power parity was in 1992 about the same as for Pakistan at US\$ 2,950 (UNDP, 1995). While there have been fluctuations in both agricultural and industrial real wages, the general tendency has.been of a stagnant or slightly downward trend during the 1980s. As a result of very low wages, devaluation and productivity increases, unit labor costs (in US\$ terms) fell faster in Indonesia than most of its Asian competitors and this has been a critical factor in putting Indonesia at an increasing advantage in international markets for labor-intensively produced goods (Godfrey, 1993). It is primarily the very low level of wages that resulted in the more recent industrial unrest in 1994, and has made the Government realize that some fundamental changes in economic policy are urgently needed as reflected in the Second 25Year Long Term Development Program PJP II (1994-2019).

\section{The Economic Impact of International Migration in the Philippines and Indonesia}

It is not the purpose of this paper to examine the factors and economic policies which were responsible for the relative economic performance of these two countries over the last two and a half decades. There is a large body of literature on the subject and a growing (neo-liberal) consensus on economic policies and reform measures needed to push countries to a more efficient and sustainable growth path which could also have a favorable impact on poverty alleviation and income distribution.

In terms of the economic impact of international migration on economic development, it is much easier to deal first with Indonesia where the dimensions of the labor flows and the financial flows associated with it were small, almost negligible, in the wider context of the national economy.

Nayyar (1996) identifies three discernible phases in international migration from Indonesia (see Table 1). Starting in 1969 to 1979 nearly half of the total emigration was to Europe, mostly to Holland, shaped by post-colonial ties. The second phase, from 1979 to 1989 , saw the country enter the emigration 
TABLE 1

EMIGRATIONFROM INDONESIA, 1969-1994

\begin{tabular}{lrrrrr}
\hline Destination & Plan I & Plan II & Plan III & Plan IV & Plan V \\
& $1969-1974$ & $1974-1979$ & $1979-1984$ & $1984-1989$ & $1989-1994$ \\
\hline $\begin{array}{l}\text { Middle East } \\
\quad \text { of which: }\end{array}$ & - & 4,752 & 60,093 & 226,030 & 390,556 \\
$\quad$ Saudi Arabia & - & 3,817 & 55,976 & 223,573 & 384,822 \\
$\begin{array}{l}\text { Southeast Asia } \\
\text { of which: }\end{array}$ & 21 & 3,008 & 16,461 & 49,251 & 215,492 \\
$\quad$ Malaysia & 12 & 536 & 11,441 & 37,785 & 156,312 \\
$\quad$ Singapore & 8 & 2,432 & 5,007 & 10,537 & 48,896 \\
East Asia & 473 & 1,748 & 2,681 & 2,308 & 21,569 \\
Europe & 3,794 & 7,083 & 14,020 & 7,543 & 10,118 \\
$\quad$ of which: & & & & & \\
$\quad$ Holland & 3,332 & 6,637 & 10,104 & 4,375 & 5,515 \\
United States & 146 & 176 & 2,981 & 6,897 & 13,993 \\
Others & 1,190 & 275 & 164 & 233 & 544 \\
TOTAL & 5,624 & & 96,410 & 292,262 & 652,272 \\
\hline
\end{tabular}

SOURCE: Ministry of Manpower in Nayyar (1996).

boom to the Middle East, mostly to Saudi Arabia, as almost three-fourths of total emigration was in that direction. The more recent 1989 to 1994 period has seen a striking increase in the relative importance of Southeast Asia, which accounted for one-third of total emigration, mainly to Malaysia and Singapore. However, the Middle East, essentially Saudi Arabia, still accounted for the major share of emigration during this period.

In terms of numbers, emigration from Indonesia of recorded migrants increased from 5,624 during 1969-74 (REPELITA I) to 652,272 during 198994 (REPELITA V). In 1993, annual labor outflows were 166,244, of which Saudi Arabia was the major destination (61.2 percent), followed by Malaysia (20.1 percent), Singapore (7.1 percent) and Taiwan/China (3.1 percent). However, a significant number of workers leave Indonesia unofficially and according to one claim, more workers leave Indonesia unofficially than officially for temporary employment abroad (Martin, 1995). Thelarge concentration of illegal Indonesian workers is in nearby Malaysia, where the men are employed on plantations and construction sites and the women are employed in factories and in domestic service. While official statistics report that there are 220,000 Indonesian migrants in Malaysia, a wide range of sources suggests that the number may be as high as 750,000 . 
TABLE 2

OCCUPATIONAL DISTRIBUTIONOFMIGRANT WORKERS FROM INDONESIA BY SECTOR OF EMPLOYMENT 1984 - 1994 (IN PERCENT)

\begin{tabular}{lcc}
\hline \multicolumn{1}{c}{ Sector } & Plan IV1984-1989 & Plan V1989-1994 \\
\hline Domestic services & 70.2 & 60.2 \\
Agriculture & 11.8 & 22.3 \\
Transportation & 14.2 & 13.8 \\
Construction & 1.5 & 0.1 \\
Electricity & 0.3 & 1.0 \\
Others & 2.0 & 2.6 \\
\hline
\end{tabular}

TOTAL

(Number of migrants)

SourCE: Ministry of Manpower in Nayyar (1996).

The skill composition of migrants, as shown by official sources, is dominated by workers in domestic services, agriculture and transportation (see Table 2). According to official sources during 1989-94, domestic services (almost exclusively females) accounted for 60.2 percent of the total migrant workers, followed by agriculture, (22.3 percent, mainly plantations), and transportation (13.8 percent). There are two striking attributes to international labor migration from Indonesia. The first, that the majority of migrants are women. During 1984-94, two-thirds of the migrants from Indonesia were women.Second, that there are almostnomigrants with professional expertise. As regards the latter, it is important to mention that there were 57,100 expatriates, mostly in management, professional and supervisory category working in Indonesia in 1995, a 38 percent increase over the previous year. They were being paid $\$ 200$ million each month (The Jakarta Post, January 23; 1996). This could indicate a shortage of professional expertise and could explain to some extent the insignificant number of migrants in this category from Indonesia.

In 1990, according to Nayyar (1996), official labor outflows from Indonesia amounted to a minuscule 0.13 percent of the total workforce, but constituted a more significant 6 percent of the increment in the workforce. Although estimates of unemployment and underemployment are characterized by serious conceptual and statistical limitations, it is worth noting that in 1990, emigration from Indonesia was 4 percent of the total unemployment and 0.35 


\section{TABLE 3}

REMITTANCES FROMINDONESIAN WORKERS

\begin{tabular}{rcc}
\hline Year & $\begin{array}{c}\text { Bank of Indonesia } \\
\text { Estimates }\end{array}$ & $\begin{array}{c}\text { Ministry of Manpower } \\
\text { Estimates }\end{array}$ \\
\hline $1987-88$ & 90 & 90 \\
$1988-89$ & 103 & 114 \\
$1989-90$ & 188 & 188 \\
$1990-91$ & 139 & 180 \\
$1991-92$ & 150 & 239 \\
$1992-93$ & 264 & 264 \\
$1993-94$ & 291 & 353 \\
$1994-95$ & 344 & 480 \\
\hline
\end{tabular}

SOURCE: Bank of Indonesia and Ministry of Manpower in Nayyar (1996).

NoTE: The data in the table relate to financial years.

The Bank of Indonesia estimates for 1993-94 and 1994-95 are projections.

percent of the total underemployment in the economy. Since a significant amount of the emigration particularly to the Middle East was temporary, so that withdrawal of labor was followed by re-entry, the above estimates need to be reduced by the amount of return migration. According to Nayyar's (1996) estimates based on official statistics, during the period 1989-1993 return migration inflows were about 45 percent of emigration outflows. Correcting for these estimates of return inflows and adding back an estimated equal number of illegal migrant workers, it is clear that the overall impact of emigration on the labor market was not that significant. Nonetheless, a reduction of 6-10 percent (as in more recent years outflows have increased) of the increment in the labor force to outside employment must notbe completely underestimated.

In principle, remittance inflows attributable to international labor migration can alleviate the savings constraint and the foreign exchange constraint, thus enabling the economy to attain a higher rate of growth. However, as Nayyar (1996) shows, remittance inflows to Indonesia as reported in official statistics are small enough to be treated as negligible in the context of the national economy. According to the Bank of Indonesia estimates (which are somewhat lower for selected years as compared to the Ministry of Manpower estimates), remittances from Indonesian workers increased from $\$ 90$ million in 1987-88 to $\$ 344$ million in $1994-95$ ( $\$ 480$ million according to the Ministry of Manpower, see Table3). In the early 1990s, remittances were equivalent to 
a mere one percent of export earnings. They were also insignificant in relation to macrovariables. In 1992 for example, remittances were the equivalent of 0.2 . percent of GDP, 0.4 percent of private consumer expenditure, and 0.8 percent of gross domestic fixed capital formation. In contrast, the total wage bill of expatriate workers was close to $\$ 2.5$ billion in 1995 (The Jakarta Post, January 23, 1996).

The official evidence on remittances is puzzling as the level of remittances per capita is only a fraction of what it is in other Asian labor-exporting countries. At the end of 1993-1994, according to official statistics there were about 625,000 Indonesian migrants working abroad. Evidence based on different sources suggests that there were at least an equal number of illegal migrants abroad. This would make for a total migrant population abroad of about 1.2 million which is comparable to the estimates for migrant population abroad of India and Pakistan where remittances are in the range of US\$3 billion. It is reasonable to infer that remit-tance inflows to Indonesia are underestimated because they are unreported.

Based on his review of labor and remittance flows, Nayyar (1996) concludes that "the macroeconomic significance therefore, is qualitative rather than quantitative and the impact of international migration on the national economy is far less than in other Asian countries, say the Philippines or Pakistan. But it cannot be ignored" (Ibid, p. 26).

Turning now to the Philippines, Saith (1996), points out that Filipino migration has occurred in five waves, the last three of which have fed intoeach other. The first wave runs from 1906 to 1934 , almost entirely to Hawaii which by 1934 had more than 120,000 Filipinos. But as of 1929,41 percent of the Filipinos left Hawaii, either to return to the Philippines, or to move on to the harvest picker trails in the United States. The period $1934-65$ could be regarded as the lull before the next tidal wave. The third phase began in 1965 with the lifting of the nationality based United States immigration quota system, from which Filipinos were able to take quick advantage. Most of thesenew migrants were highly skilled professionals. The period also witnessed the entry of Filipino seamen into the emigration stream. The fourth phase, starting in the early 1970 s to the now oil-rich Gulf countries accelerated after 1976. The final and fifth wave which continues into the present, although much smaller than the Middle Eastern one, has seen a significant rise in the share of emigration to the rapidly growing Asian economies, mainly Japan, Taiwan/China, Hongkong, Singapore and Malaysia. This period has also seen a sharp rise in the number of seamen deployed overseas.

This brief historical review is important, for to be able to gauge the impact of migration on the national economy one needs to differentiate between the three different streams of emigration from the Philippines. The first are the permanent emigrants, the second the recorded (or documented, or official or legal) overseas contract workers (OCWs), and third the unrecorded (or 
TABLE 4

DEPLOYEd LAND-Based FIIIPINOOVERSEAS CONTRACT.Workers (OCWs) BYREGION/MAJOR COUNTRY

\begin{tabular}{lrrrrr}
\hline Region/Country & 1975 & 1987 & 1992 & 1993 & \multicolumn{1}{c}{1994} \\
\hline Asia & 4,217 & 90,454 & 144,489 & 183,877 & 211,951 \\
Hong Kong & 865 & 30,811 & 52,261 & 62,583 & 62,161 \\
Japan & 2,275 & 33,791 & 51,949 & 45,542 & 54,879 \\
Taiwan & 33 & 3 & 1,193 & 23,025 & 34,387 \\
Middle East & 1,552 & 273,038 & 360,458 & 325,645 & 312,199 \\
$\quad$ Saudi Arabia & 353 & 197,219 & 260,112 & 230,996 & 215,351 \\
UAE & 0 & 24,168 & 28,839 & 30,045 & 27,713 \\
Europe & 3,160 & 5,643 & 15,439 & 14,429 & 12,568 \\
Americas & 2,285 & 5,614 & 15,439 & 13,143 & 13,758 \\
Africa & 342 & 1,856 & 2,654 & 2,606 & 3,573 \\
Oceania & 551 & 1,271 & 1,765 & 1,618 & 1,413 \\
Trust Territories & 394 & 5,373 & 11,814 & 9,554 & 9,264 \\
TOTAL & 12,501 & 382,229 & 549,655 & 550,872 & 565,226 \\
\hline
\end{tabular}

SOURCE: Philippine Overseas Employment Administration, cited in DOLE (1995, p. 5).

und ocumented, unofficial or illegal) flows outwards. The behavior of the first, in relation to the other two can be quite different, especially as regards the flow of remittances, and the use of remittances by the receiving households.

As regards outflows of land based Filipino overseas contract workers (OCWs), these increased from 12,501 in 1975 to 565,226 in 1994, while the total number including sea-based OCWs was 719,602 in 1994 (see Table 4). In the same year, the largest number of deployed land based OCWs was in Saudi Arabia $(215,631)$, followed by Hongkong $(62,161)$, Japan $(54,879)$, Taiwan/ China $(34,387)$ and the UAE $(27,713)$. In 1994, about 48 percent of the total deployed OCWs were females but they accounted for almost 60 percent of the new hires. By occupation, service workers, production and related workers and seafarers accounted for the bulk of totalOCWs over the past thirty years. Because of the building boom in the Middle East in the 1970s and early 1980s, the share of production and related workers rose from 3.4 percent in 1995 to 47.3 percent in 1980 and 38.6 percent in 1985 . This figure slid to 23.5 percent in 1991. In 1993, the bulk, 88.7 percent of newly hired construction workers, were still bound for the Middle East. According to the White Paper on the overseas employment program published by the Department of Labor and Employment (DOLE), it is important to note that, "The majority of new hires in 1994 were in the vulnerable occupations, with domestic help ( 26.34 percent) 
and entertainers (18.17 percent) accounting for almost half of total new hires. In such occupations, about 95 percent are women" (DOLE, White Paper, 1995, p.7).

Mainly thanks to the pioneering and painstaking work of a number of key studies especially by Abella (1993), Alburo (1993), Tan (1993), and most recently by Saith (1996), it is now possible to thread together an estimate of the stocks and flows of emigrants from the Philippines, and have some better feel for the interpretation of the total amount of remittances which has flown into the economy over the last decade and a half.

According to Saith (1996), the total number of Filipino permanent migrants in the United States can be estimated at just over two million and the circulatory stocks for 1994 in the range of 1,523,000 to 2,057,000. Putting these together, i.e. the total permanent emigrant stock and the range of estimates of total circulatory stocks and some allowance for the existence of "clandestine" workers (mostly in Japan, Taiwan/China, Singapore and Malaysia), Saith comes up with an overall number which, "might not be too far from the figure of 4 million cited by President Ramos for the size of the Filipino diaspora, or the 4.2 million estimated in the recent White Paper" (Saith 1996, p. 25).

To take into account the labor market effects of this migration the impact is most vividly illustrated by the recent report of the World Bank (1995a) which states that "Migration has helped to reduce unemployment by almost 40 percent. ... The urban unemployment rate rose to 14 percent in 1991 . However, a complete return of all overseas workers in 1991 would have increased unemployment substantially. Under this counterfactual scenario, urban unemployment would have been as high as 20 percent in 1991 had all migrants returned (an increase of 40 percent over the actual unemployment rate)." (World Bank, 1995a, p.62). Saith (1996) estimates that in terms of the annual flows an additional 775,000 persons in 1994 joined the active labor force. The total deployment of Overseas Contract Workers (OCWs) for the year was 719,602 (see Table 5). If one restricted the figura to only to land-based new hires $(268,711)$, the offtake on account of international migration would be 34.7 percent of the total incremental active labor force for the country. Adding on the "new hires" for the seafarers would further raise the percentage to forty percent or above.

While it is difficult to ascertain the actual extent of underestimation of total remittances during the last twenty years, it is clear that the importance of remittance flows for the Philippine economy, and for the workers and their families that generate them, cannot be overstated. While cognizant of the fact that the official remittance estimates for more recent years may well include return flows of capital transfers abroad they do at the same reflect response to a morestable politicalenvironment and a less distorted ex-change rate and more opportunities in the capital market. In 1994, the remittance flows 
TABLE 5

PHILIPPINES

OUTFLOWSOF OvERSEAS CONTRACT WORKERS (OCWs) AND INFLOWS OF REMITTANCES 1975 - 1994

\begin{tabular}{|c|c|c|c|c|c|c|}
\hline \multirow[t]{2}{*}{ Year } & \multicolumn{3}{|c|}{ Deployed OCWs } & \multicolumn{3}{|c|}{ Remittances ('000US\$) } \\
\hline & Land & Sea & All & Land & Sea & All \\
\hline 1975 & 12,501 & 23,534 & 36,035 & 71.1 & 31.9 & 103.0 \\
\hline 1976 & 19,221 & 28,614 & 47,835 & 67.0 & 44.0 & 111.0 \\
\hline 1977 & 36,676 & 33,699 & 70,375 & 153.6 & 59.4 & 213.0 \\
\hline 1978 & 50,981 & 37,260 & 88,241 & 208.8 & 82.0 & 290.9 \\
\hline 1979 & 92,519 & 44,818 & 137,337 & 264.6 & 100.2 & 364.7 \\
\hline 1980 & 157,394 & 57,196 & 214,590 & 299.7 & 121.6 & 421.3 \\
\hline 1981 & 210,996 & 55,247 & 266,243 & 383.7 & 162.2 & 545.9 \\
\hline 1982 & 250,115 & 64,169 & 314,284 & 642.3 & 168.1 & 810.5 \\
\hline 1983 & 380,263 & 53,944 & 434,207 & 660.1 & 284.4 & 944.5 \\
\hline 1984 & 300,378 & 50,604 & 350,982 & 472.6 & 186.3 & 658.9 \\
\hline 1985 & 320,494 & 52,290 & 372,784 & 597.9 & 89.3 & 687.2 \\
\hline 1986 & 323,517 & 54,697 & 378,214 & 571.7 & 108.7 & 680.4 \\
\hline 1987 & 382,229 & 67,042 & 449,271 & 671.4 & 120.5 & 791.9 \\
\hline 1988 & 385,117 & 85,913 & 471,030 & 683.3 & 173.5 & 856.8 \\
\hline 1989 & 355,346 & 103,280 & 458,626 & 755.2 & 217.8 & 973.0 \\
\hline 1990 & 334,883 & 111,212 & 446,095 & 893.4 & 287.7 & $1,181.1$ \\
\hline 1991 & 489,260 & 125,759 & 615,019 & $1,125.1$ & 375.2 & $1,500.3$ \\
\hline 1992 & 549,655 & 136,806 & 686,461 & $1,757.4$ & 445.0 & $2,202.4$ \\
\hline 1993 & 550,872 & 145,758 & 696,630 & $1,840.3$ & 389.3 & $2,229.6$ \\
\hline 1994 & 565,226 & 154,376 & 719,602 & $2,560.8$ & 379.4 & $2,940.2$ \\
\hline
\end{tabular}

SOURCE: Saith (1996). 
entering officially through the banking channel which were stated at $\$ 2.94$ (Table 5) billion amounted to over 20 percent of export earnings, and as much as 4 percent of GDP in 1994. The real significance is greater. The 1994 remittances financed over 50 percent of the external trade balance. In the crisis years of the mid-1980s the figure was much higher, standing at 124 percent in 1985. In 1994, remittances were more than twice the net inflow of foreign investment. Given the boom-bust cycle of Philippine economic growth, triggered usually by an external sector crisis, Saith concludes that "this inflow would appear to be indispensable" (Saith 1996, p.16).

Clearly, the impact which these remittance flows, from both official and unofficial channels, could have on macroeconomic growth are critically dependent on theoverall economic policy environment and the linkages that exist between these flows and domestic economic expansion. It is clear that both the macroeconomic environment in the Philippines and the inefficient and non-competitive structure of the economy, with its domination by large firms and the bias in the incentivestructure and financial system against small and medium sized firms, all meant that the actual contribution of remittances to economic growth was greatly diminished and the opportunities that remittances could have opened up were definitely lost in the 1980s.

At the same time, the above analysis clearly illustrates the far-reaching impact emigration has had on the Philippines economy. The outflow of labor provided a safety value to the deteriorating domestic employment situation and remittances were indispensable for the external sector. One further important issue needs to be taken up in the context of the migration development nexus: that is the impact of remittances in alleviating poverty in the country. The premise of this argument has been that the overseas contract workers mainly came from the lower-middle and poor income groups, even if they are not from the poorest income groups. Besides the direct increases in income levels for households receiving remittances, the expenditure from this additional income especially in housing and the services sector would have had a favorable impact on employment generation and poverty alleviation in the economy. The fact that during the period of the 1970s, poverty levels showed very little change when the Philippine economy grew at a respectable rate, and during the period of the 1980s, poverty levels declined, even though marginally when there was hardly any growth, could perhaps be explained through remittance flows into the economy.

Again, Saith's (1996) recent study provides some pioneering insights based on a careful analysis of the National Income and Expenditure (NIE) Survey, 1991 (together with 1988 and 1985), of the relationship between migration and poverty in the Philippines. The first important finding of the study is that overseas migrants come disproportionately from a few regions, 
most of them on the richer end of the scale. The incidence of overseas migration is most pronounced in four regions, viz., the National Capital Region (NCR) i.e., Metro Manila, Ilocos (with its historical links), Southern Tagalog and Central Luzon. These findings based on the NIEs 1991 data, are confirmed in the two earlier rounds in 1988 and 1985. The evidence also shows that for the country as a whole, this incidence is very low for the lowest income classes, and rises sharply at the upper end of the income scale. For the country as a whole, the lowest decile received only 1.1 percent of its total income from abroad; for the highest one, the percentage was 11 times higher at 12.2 percent. The data also reveal that at country level, the urban percentage is twice as high as the rural one.

As far as the direct effect of migration is concerned, Saith (1996) argues that there is clear evidence that "the benefits accrue disproportionately to the richer regions, sectors and classes" (Ibid, p. 29). The idea that female domestic helpers would be drawn from the poorest sections of the community is somewhat misplaced - field studies show that migrant female domestic helpers in South-East Asia tend to be relatively better educated than the general female population in the corresponding age groups. However, if we examine the reverse side of the coin, i.e., internal migration, this shows the richer regions as the receiving areas and some of the poorer regions as the heavy sending out areas. Again, in sharp contrast to income receipts from abroad, poorer regions in general get a much higher proportion of their income from income receipts from domestic sources than do the richer regions. Across the full range of receipts, the poorer classes rely far more on domestic receipts, while the opposite is true for families in the upper income deciles.

Saith (1996) therefore concludes that, "The overall pattern is suggestive of a dualistic labor migration phenomenon, where domestic migration involves shifts of population from the poorer to the richer regions, but not abroad, and a separate one from the richer regions to overseas destinations" (Ibid, p. 30). Migration then could claim to be regarded as a "trickle-down" mechanism of operating through the labor market effects. In the absence of heavy migration overseas, it is arguable that in counter factual terms, the labor market in the sending region would have been more depressed and could not have opened the way for domestic migration from the poorer regions.

That remittances may have contributed for some of the recent decline in poverty levels from 1991 to 1994 could also find some support in Saith's analysis which shows that during 1988 and 1991, there was a much faster growth rates of OCWs in the poorer regions than for the richer regions. This would suggest that a much faster expansion of numbers of OCWs going abroad between 1988 and 1991 (from 486,000 to 721,000) may have pushed the contours of recruitment into the poorer provinces. 


\section{Negative Impact of Overseas Migration}

It would, however, be wrong to leave the general impression that the macroeconomic impact of overseas migration is mostly favorable. There are two areas which have always been of considerable concern. The first is the loss of professional and higher skilled workers, the "brain-drain", which even though it may not result in shortages in the medium and long term, still means a loss for the economy as the costs of their education and skills development were borne to a large extent by the state. The second is the impact of migration on domestic wages and creation in the short term of skill shortages in the economy. As regards the former two important points may benoted. The first is that as compared to some of its ASEAN neighbors the level of real wages is higher in the Philippines. The second is that during the 1980s despite a sharp decline in labor productivity, the overall trend in real wages was positive. Could migration have resulted in this impact on the domestic labor market? The answer to this question would weigh towards the negative. Given the existing high levels of unemployment and underemployment during the depressed years of the 1980 s, overseas migration acted more as a safety valve to the deteriorating labor market situation rather than leading to a tighter labor market, except in the case of a few selected skills, the shortages of which were overcome in a fairly short time. What perhaps took longer to remedy was the loss of experienced workers and therefore quality and productivity may have suffered for a somewhat longer time frame.

\section{Emigration Pressures and Structural Change}

The debate and analysis on issues related to emigration pressures has focussed attention on how the process of economic development has induced and shaped international labor migration. The experience of Japan and the Republic of Korea, as well as Singapore and Hong Kong (to a lesser extent), are cited to show the dynamics of this transformation. Two important stages in this process are identified. The first is the stage which a country reaches in its development process, or "turning point", when it is no longer attractive for the domestic labor force to actively seekemployment abroad. The second, or subsequent stage, termed as the "international migration turning point," is reached when domestic labor supplies need to be supplemented by inflows of foreign workers.

It is important, however, to point out that the first "turning point" can emerge even at a stage when there still exists surplus and underemployed labor in the economy, as the domestic work force finds that it is no longer attractive to seek jobs abroad at the wage rate being offered. The country can alsobecome an importer of labor before reaching the level of full employment. This would happen even before reaching the Lewisian turning point if the 
relative wage level in the economy becomes higher than that existing in the immediateneighbouring countries and would result in the work force of these countries trying to find employment (legally or illegally) in the higher wage economy.

The important point to note, and this is sometimes forgotten, is that what determines competitiveness in export labor markets in not the differential between the wages in the labor-sending and labor-receiving country per se, but the wage level at which labor in a country is prepared to seek employment overseas as compared to its other competitors in overseas markets. The result is that emigration pressure may drop for particular kinds of jobs overseas well before the country reaches the Lewisian turning point (Lewis, 1954). Pakistan is a good example for showing the different migratory pressures to which a labor surplus economy can be subjected. In recent years, it has gradually outpriced itself for unskilled jobs in the Middle East (which were taken by workers from Bangladesh and Sri Lanka), it has found itself subject to large scale in-migration (almost 1 million illegal migrants from Bangladesh) and is still at the same time a significant exporter of skilled labor to the Middle East and unskilled labor to the East Asian economies.

A similar set of complex issues are raised in defining "demand" for foreign workers in the labor-receiving countries. In most countries, the total numbers tobe allowed legally for work are fixed by the governmentafter taking into consideration the felt needs of the economy. The level at which this number is fixed may not represent the real total demand in the economy for migrant workers. If the difference between what the government officially allows and the real need of the economy is large, then the pressures for illegal migration would increase. The government could then have two options. The first is to turn a "blind eye" to illegal migration (as is done in Japan) and not officially recognize the existence of these illegal foreign workers, while the second is to aggressively ensure that it is extremely difficult for illegal migrants to enter the country, and to deport the illegal migrants found in the country. The level of total demand for migrant workers in the labor-receiving countries is again a function of the supply or growth in the labor force, the age-structure of the population and, on the demand side, the structure and growth points in the economy (e.g., workers needed in the construction or services sector). It is also influenced by attitudes of the domestic labor force to certain kinds of jobs (e.g., the 3D/4D jobs) which they may not be willing to undertake.

The current debate on emigration pressures, has placed emphasis on both supply-side push factors and demand-induced pull factors. But this debate has suffered from the fact that it has been carried out far too much in broadaggregate supply/demand analysis and in the process, at times the multifaceted and complex dynamics of this process has been lost. Migration in many cases, results from a host of factors including the labor-sending country's 
geographic location in relation to its relatively more developed neighbors, historical and cultural ties and the ease with which it is possible to cross international borders, and these and many other factors are at times overlooked in the current debate in terms of broad supply and demand factor analysis.

\section{Emigration Pressures in Indonesia and the Philippines}

We start by examining the situation in Indonesia. From the supply side, Indonesia has experienced a rapid growth in population during the last 25 years and the growth rate of the labor force has been even higher. Between 1971 and 1980 , its population increased at an average rate of 2.4 percent per annum and during the 1980 s at an average rate of 2 percent per annum. Between 1971 and 1980, the labor force increased by 2.7 percent per annum. The sharp increase in the labor force during the 1980 s can be attributed to a combination of demographic factors (as young persons reached working age) and increasing female participation rates (as women entered the labor market).

On the demand, Indonesia has witnessed a rapid expansion of employment in the manufacturing sector, mainly through an extremely high growth of employment-intensive manufactured exports. The overall policy environment that resulted from the economic reform process has on the whole been "employment-friendly." The resulting increase in employment growth, although impressive, especially in the manufacturing sector has still not been sufficient to productively absorb the rapid growth of population and the labor force. Godfrey (1993) has analyzed in considerable detail the process of labor absorption in Indonesia mainly through following movements in wage rates in the key sectors and across provinces, and comes to the conclusion that Indonesia still has a long way to go before it reaches the Lewisian turning point, when there is pressure for real wages to increase as the surplus labor from the agriculture sector begins to get exhausted.

Nayyar (1996) observes that Indonesia is still in the stage which can be described as the "extensive margin of labor absorption," where surplus labor is being transferred from the agricultural sector into the manufacturing or the services sector at existing level of wages. Therefore, despite the much reduced incidence of poverty, there remains a reservoir of surplus labor and poor people in rural Indonesia. It is this existence of surplus unskilled workers, particularly women, who in search of employment opportunities, turn towards the overseas market. Migration across national boundaries is that much more attractive as wages in possible countries of destination are four to eight times wages in Indonesia. The "turning point" would come if and when Indonesia makes themigration transition from being a labor surplus economy toone which is much nearer the level of full employment. This would happen 
when the economy moves to what can be described as the "intensive margin of labor absorption," when there is an increase in average productivity of labor in the agricultural sector which results in an increase in real rural wages. Until then, as Nayyar suggests, "the pressures to migrate from rural Indonesia would persist on the supply side, and workers would continue to move to urban settlements or overseas destinations attracted by better employment opportunities or higher wages on the demand side" (Nayyar 1996, p.41).

In the case of the Philippines on the side of supply, a population growth of 2.1 percent per annum must be considered high in relation to female educational levels and female labor force participation rates. Against this population growth rate, the labor force grew much faster at 2.9 percent per year, amongst others as a result of a noticeable increase in the overall labor force participation rate from 60.1 percent in 1982 to 65.2 . The interaction of this high growth rate of the labor force and the almost stagnant growth rate of GDP in the 1980 s meant that aggregate labor productivity plummeted, falling at 2.6 percent per year. The levels of unemployment remained at around 9 percent during this period and underemployment at over 20 percent. With hardly any growth in productive job creation, most Filipinos found themselves pushed intolow income and low productivity jobs in theinformal and services sector. Others turned towards jobs outside national boundaries.

The factors explaining the low levels of labor absorption in the Philippines economy are very similar to those mentioned earlier which were responsible for the weak impact of remittances on employment and income growth in the economy. The anti-agricultural bias was manifest in the exchange rate and implicit tax regime. Another aspect of undervaluation of capital was the heavily labor displacing mechanization in agriculture. The industrial sector, with its massive bias in favor of large-scale, capital-intensive plants, displayed extremely weak linkages with the rural sector and generated limited development spread effects. The lack of competitiveness in the domestic markets mainly as a result of monopolistic domination of large firms and vested interest groups all combined tocreate an inefficient economic structure which was positively hostile to employment growth in marked contrast to the employment-friendly policy regime which characterized Indonesia's development during the same decade.

\section{Policy Perspectives}

It is quite clear that labor supply pressures even in the face of favorable overall economic growth and "employment-friendly" policies, will dominate the overall performance of the labor market in the Philippines and Indonesia at least over the next decade. While these supply pressures receive directed attention on the need to give the highest priority to generating employment- 
intensive growth, there has also been an emotive and soul-searching debate in the Philippines on the role overseas migration should be assigned in the overall developmentstrategy. In Indonesia too, government pronouncements clearly indicate a shift in policy objectives by gradually phasing out migration of domestic helper and moving towards the export of more highly skilled workers.

Do these shifts in policy perspectives imply a premature migration transition in these countries?

\section{Outright Ban or Phasing Out?}

It may be important to start by considering the view, which is no longer considered that extreme, of placing an outright ban on the export of female workers and the gradual phasing out of overseas contract workers from the migration stream. In the early 1980s, such a ban was imposed on the export of female domestic helpers from Indonesia and there are pressures from time to time for the reimposition of the ban. In the Philippines very recently, following the Flor Contemplacion case, the Gancayco Commission of Inquiry set-up to examine this issue, also called for a phasing out of a sub-stantial part of overseas migration over a five year period.

The fact that a very large proportion of migrants from both the Philippines and Indonesia are female workers would mean that an outright ban would impact upon more than half of the migration stream from these two countries. In examining what the impact of such a ban might have, three sets of issues need to be examined: the first, as to what would be the impact on the domestic labor market and remittanceflows; the second, its impacton incomes and efforts at reducing poverty; and finally, how feasible it would be enforce such $a$ ban and, if not, whether the resulting situation would in fact serve the objectives for which the ban is being imposed in the first place.

However, before these issues are discussed, it is important to place on top of the agenda the growing public concern in the labor-sending countries over the increasing evidence of exploitation and abuse of female migrant workers in their host country. In a recent article, Lim and Oishi (1996) have systematically analyzed the policy challenges that the growing feminization of Asian labor migration poses and, given the limited effectiveness of labor-sending countries to improve their working conditions, thenecessity for more government and international efforts to guarantee the basic human rights of this vulnerable group. The study points out that women usually must emigrate in their own right, as autonomous migrants, because receiving countries in Asia and the Middle East generally do not allow families in. There is a number of restrictions on their employment. For example, foreign domestic helpers in a number of Asian countries are often not allowed to change jobs within two years of their employment contracts. Migrantwomen workers are prohibited 
from marrying with local citizens, they are not allowed to become pregnant, and some countries can even subject them to pregnarcy tests every six months.

According to this study, among the ind ustries fuelling demand for Asian female workers "entertainment" is frequently a euphemism for prostitution. Outright prostitution is widespread and, in many cases, women contracted to work legitimate jobs are then forced into prostitution. Women in any occupation whoenter countries illegally or overstay their visas are subject to exploitation, but so-called entertainers are particularly vulnerable.

In the case of the Philippines, out of the total workers deployed in 1994, 10,491 or 1.86 percent wereentertainers. For domestichelpers, the percentage was much higher at 13.58 percent, but still a small fraction of the total. However, as mentioned earlier (p.11), in terms of new hires, these two categories accounted for almost half of the total. In recent years, the Philippines has instituted a number of policy controls and restrictions toensure that only genuine "entertainers" are allowed to leave the country (there is a selective ban on certain countries of destination, and women must be at least 23 years old and possess an Artist Record Book and undergo pre-departure showcase preview). The same is true for domestic workers (at least 25 years of age and a selective ban on certain countries of destination).

While these checks and restrictions may have helped to somewhat improve the situation at the same time, it is quite clear that since the roots of the problem lies in the host countries, women workers continue to face considerable hardship and physical, sexual and other forms of exploitation. It is rightly feared, however, that an outright ban on their emigration may in fact worsen rather than improve the situation, by driving such emigration underground and exposing such women migrants whose status would now be of illegal migrants to even greater exploitation, especially by well-organized underground syndicates.

In the circumstances therefore, what is needed is a concerted effort at both the national and international level to institute measures and checks which can help bring about a significant change in the present deplorable situation. Lim and Oishi (1996) havesuggested a number of concrete recommendations, including moreemphasis on providing potential emigrants with reliable and accurate information as to what they can expect in their overseas jobs, and wherever possible, migrants themselves being aided and encouraged to develop their own support structures and networks. The study also draws attention to the fact that in the absence of new regional or international initiatives, international labor standards assume greater significance. The adoption of specific ILOConventions designed to assist migrants and secure equality of treatmentbetween nationals and non-nationals (ILOConvention No. 97, Migration for Employment, 1949) and Convention No. 143 (Migrant Workers 1975), which call upon Governments to respect the basic human rights of all migrant workers, male and female, to prevent clandestine migra- 
tion for employment and stop manpower trafficking activities, could play an important role in bringing about such an improvement.

\section{Phasing Out}

To phase out overseas migration in the Philippines over the next few years would be difficult even if the economy were to achieve "entigerment" and reach the almost two digit sustained growth rates of its East Asian neighbors. The same is true of Indonesia. The existing levels of unemployment and underemployment and the growth rates of the labor force are just too high to make this happen.

What then would be the impact if this was done? Before we answer the question, it is important to first clarify what could be envisaged as the process of phasing out of the migration stream of overseas contract workers. As regards outmigration, it could mean reducing by say 20 percent each year the present number who leave as OCWs. As regards those who are at present working overseas, it would imply providing them with incentives to return and initiating programs to assist in their productive re-absorption in the domestic economy.

In the Philippines, the economic costs of such policies even if they were implementable would be high, though not disastrous, if the economy was to immediately climb on to a high growth path. In terms of the labor market impact, it would increase pressures on the domestic labor market and make it extremely difficult to even achieve the modest targets of a decline in unemployment (to about 6 percent by 1998) which the Government has set in the Medium Term Five-Year Development Plan (1993-1998). Initially, it is quite possible that those who return may not immediately enter the labor market, as happened in the case of migrants who were forced to return after the Gulf Crisis triggered by Iraq's invasion of Kuwait (Hamid and Zahid, 1994). But in this case, the situation would be different as OCWs would be actively discouraged to again leave the country. As regards the decline in remittances, again as was shown during the Gulf Crisis, immediately there may be an increase as migrants bring back their savings accumulated abroad. Also, remittances at present have a significant share of capital flows which would find alternative ways of finding their way back to the domestic economy. But eventually, remittances would decline and this would put pressure on the balance of payments situation and could slow down the process of economic recovery. The exchange rate may decline to a more favorable rate for the export of manufactures but these adjustments can be achieved without necessarily having to gradually phase out overseas migration and the remittances that accompany them.

Perhaps the most unfavorable impact such a policy may have is in the fight against poverty, as remittances have the potential of playing an important part in boosting incomes and generating jobs in the domestic economy. Saith's 
(1996) valuable work has shown the process through which such mechanisms work and in a country where poverty levels are already extremely high, it would be unfortunate to remove this much needed assistance to national efforts at fighting poverty.

A policy of phasing out migration may also, as Saith (1996) argues, have an unfavorable impact on general perceptions of business confidence during the present economic recovery, both for overseas and domestic investors. Perceiving that such controls may be extended to other sectors, the private sector may look upon these policy initiatives with suspicion and stall the overall process of economic recovery and growth.

\section{Targeting Higher Skill Jobs in Overseas Markets}

Government policy in Indonesia is strongly of the view of the need to move away from the export of low skilled household helpers to higher skilled workers. A shift in practice to implement this policy, would remove from the migration stream the most vulnerable workers, while at the same time increase remittance flows into the domestic economy.

While in principle, the aims of such a policy are understandable and well motivated, it does not take fully into account two factors. The first is that the gradual phasing out of unskilled and low skilled workers may not be practical in that it may just lead to an increase in illegal migration of these workers. The second, and that is perhaps most important in terms of translating this strategy into practice, is that migration is primarily a demand induced phenomenon. While it may be possible to prepare the necessary supply of skilled workers for overseas market, there is no guarantee that Says Law would hold, in that supply would create its own demand. Only if such a demand exists in the labor-receiving countries and Indonesia can effectively compete with other labor suppliers in securing this market could such a policy be effectively putinto operation.

We have already touched upon the fact that in most labor-receiving countries, there exists a large gap between what the government officially allows in terms of the legal inflow of migrant labor into the country and what the actual or effective demand may be, and how this would translate itself into pressure for illegal migration into the country. This paper does not analyze this issue in any great depth and explore the magnitude of this "demand gap" or unfulfilled demand in the labor-receiving countries. In any case at a time when most labor-receiving countries are already under considerable pressure to reduce the inflows of migrant labor, and in fact there is growing pressure to even send back those who are already present, it would be optimistic to expect any significant increase in the numbers of foreign migrants being allowed into the country at least at the "official" level. 
However, this being said, two issues can be briefly touched upon while analyzing the demand aspects of overseas migration. The first is how economic globalization would impact upon this phenomenon and secondly, how structural changes in the more well to do countries could impact upon the demand pattern for migrant workers.

The rapid pace of economic globalization has been made possible by the process of liberalization and the opening up of national economies to a far freer flows of goods and movements of capital. It should result in more efficient economic structures emerging based on a country's comparative advantage. This would imply that labor surplus economies would specialize far more in the production of labor-intensive goods and economies facing labor shortages in more capital-intensive and skill-intensive production. A freer movement of capital should now further accelerate the trend of multinational corporations moving production from high wage to lower wage economies. This should mean that industries located in advanced or semi-industrialized countries which were dependent on the use of cheaper migrant labor, should now be undergreater pressure to move production folow wage, labor surplus economies. In a world where in the foreseeable future there will remain major barriers to the movement of labor but much greater movement of goods and capital, a lessening of demand should result for foreign workers in industries located in labor scarce economies, which become increasingly non-competitive as a result of increasing trade liberalization and international competition.

From the point of view of the labor-sending country, is the relocation of industries as a result of a freer movement of capital a more preferred solution to its problems of unemployment and underemployment as compared to the export of workers abroad? While clearly this is an issue which needs to be analyzed in much greater detail, it would seem, apriori, that given the much greater linkages foreign industrial investment could generate with the domestic economy, it would be the preferablesolution. However, this would depend crucially on linkages, both forward and backward, being developed between foreign capital generated production and the domestic economy.

At the same time, however, there will continue to remain in the advanced and semi-industrialized economies sectors and production processes which cannot be relocated and take advantage of lower labor costs, although the remarkable pace of technological innovations and global communications could even breakmany of these barriers. The examples of service sector jobs, construction, plantations and domestic services are normally cited in this regard. To this list, one may again add the $3 \mathrm{D} / 4 \mathrm{D}$ jobs.

Globalization should also result in a demand for a more skill-intensive and new technology literate work force in the more advanced labor-scarce economies. However, the total number of jobs that would result due to this 
restructuring would certainly be far less as compared tomore labor-intensive production processes which it would replace.

A factor which would have important implications for demand for labor in the advanced countries is the changing demographic structures of mature Asian industrial economies together with dramatic improvements in their living standards. The combination of these is likely to open up large spaces in the areas of personal services quite distinct from the stereo-typed domestic maid or entertainer. According to Saith (1996), "Thus high demand sectors could be created by a rich ageing population where traditional family structures begin to give way, for instance in personalized health care, professional household management, organized entertainment and holiday services, social and community services" (Ibid, p. 42).

The important conclusion one can draw from this rather cursory analysis of the impact of globalization and rapid economic growth in the Asia-Pacific rim on migration flows is that even if the total demand for migrant labor is not allowed to be realized, there will be some significant changes in the composition of this demand which may require higher and better skills and educational attainment as compared to the earlier flows of migrant workers.

The Indonesian strategy may therefore well be right in preparing itself for this changing structure of demand and re-orienting its education and vocational training system to meet this demand. But again, it should be borne in mind that there would be increasing competition for these jobs from the laborabundant Asian economies and not just training but linguistic skills may be equally important, as will be a host of other factors, in determining who will be able to secure these new operings. Also with the economy facing skill shortages as it continues its fast pace of growth, the government may need to reconsider its strategy for encouraging emigration manpower resources.

\section{Conclusions}

We may now draw some pointed conclusions from the analysis of migration experiences of the Philippines and Indonesia:

(i) Both economies have still a long way to go before they attain a situation anywherenear resembling one of full employment. The existing high levels of surplus labor (as reflected in estimates for unemployment/underemployment) and continuing high growth in labor supply would mean that even under the most favorable demand scenario (high labor absorptive growth) in the medium term ( 5 to 10 years), the economies of both countries would not be able to generate sufficient jobs in the domestic economies to find productive employment for their growing labor force. In this sense, both economies are still far away from the "turning point," when emigration pressures to seek employment opportunities overseas would disappear. 
(ii) At the same time, there is an important change in public and government perception in both countries of the role they wish to assign to overseas migration in the development process. The highest priority is being increasingly given in both countries to accelerate the growth of productive employment in the domestic economy and to put in place economic reforms and a policy environment which is "employment-friendly" and conducive to employment-intensive growth. Indonesia was able to do this much earlier but the Philippines has also accelerated its reform process in this direction.

(iii) In the Philippines, there is increasing pressure to slowly phase out theemigration of overseas contract workers and in Indonesia, to phase out the emigration of domestic helpers from the migration stream. Indonesia, however, would like to concentrate on the export of skilled workers so as to substantially increase manifold its present level of remittances.

(iv) It has been the increasing evidence of exploitation and abuse of female domestic workers in the host countries which is primarily responsible for this change in attitude and for the pressures building up to phase out emigration of contract workers altogether in the Philippines, and at least of domestic helpers in Indonesia. At present, almost 60 percent of migrants leaving from both countries each year are female workers.

(v) There is little doubt that the highest priority must be given to combatting the exploitation and physical, sexual and other abuse of migrant workers, especially the more vulnerable female migrants. This would require action at both the national and international level as well as by the migrants themselves in the host countries. The adoption and respect for International Labor Standards for protecting the rights of migrant workers could be an important step in this direction by the labor-sending and more importantly the laborreceiving countries.

(vi) This paper has taken the view that a policy of banning the outflows of vulnerable workers as well as deliberately reducing the outflows of overseas contract workers would not be the preferred policy option in the present circumstances. In the case of the former, it would increase illegal and underground migration which would expose the vulnerable groups of female migrants to even greater exploitation and abuse. Similarly, it has been argued that emigration flows in the present stage of economic development in both countries could have a continuing favorable impact on economic growth, employment generation and most important, poverty alleviation in both countries, although clearly this impact would be far greater in the case of the Philippines as compared to Indonesia. 
(vii) Despite the growing hostility in attitudes in the labor-receiving countries to the inflow of migrant workers, both structural and other changes (including the ageing of the population) will mean that there will be a continued reliance on foreign workers in the advanced and fast growing economies, especially in the Asian region. Even if the total numbers may not dramatically increase, there is scope to find a niche for both countries in the newly emerging pattern of demand for migrant workers.

\section{REFERENCES}

Abella, Manolo I.

1993 "Labor Mobility, Trade and Structural Change: The Philippine Experience," Asian Pacific Migration Journal, 2(3):249-268.

Alburo, Florian A.

1993 "Remittances, Trade and the Philippine Economy," Asian and Pacific Migration Journal, 2(3):269-283.

Amjad, Rashid

1989 To the Gulf and Back: Studies on the Economic Impact of International Labor Migration.New Delhi: ILO/ARTEP.

Balisacan, Arsenio M.

1996 "Policy Reforms and Poverty Alleviation in the Philippines," Manila: ILO/SEAPAT, (Draft).

Connell, John

1996 "Emigration Pressures and Structural Change in Asia and the Pacific," Manila: ILO/ SEAPAT， (Draft).

Department of Labor and Employment (DOLE), Republic of the Philippines

1995 The Overseas Employment Programme, White Paper. Manila: DOLE.

Godfrey, M.

1993 "Employment Planning Within the Context of Economic Reforms: A Case Study of Indonesia," World Employment Programme Research Working Paper, WEP2-46/ WP.39. Geneva: ILO.

Hamid, Naved and Shahid Zahid

1994 External Shocks and Policy Adjustments: Lessons From the Gulf Crisis. Manila: Asian Development Bank.

Khan, Azizur Rahman

1996 "Employment Policies for the Philippines in the Context of Liberalization and Globalization," Manila: ILO/SEAPAT.

Lewis, W. A.

1954 "Economic Development with Unlimited Supplies of Labor," The Manchester School, 22:139-191. 
Lim, Lin Lean and Nana Oishi

1996 "International Labor Migration of Asian Women: Distinctive Characteristics and Policy Concerns," Asian and Pacific Migration Joumal, 5(1):85-116.

Martin, Philip

1995 "Labor Migration in Asia." Paper presented at the 8th Workshop on Asian Economic Outlook.

Nayyar, Deepak

1996 "International Migration and Structural Change in Indonesia," Manila: ILO/ SEAPAT, (Draft).

Saith, Ashwani

1996 "Emigration Pressures and Structural Change in the Philippines," Manila: ILO/ SEAPAT, (Draft).

Tan, Edita A.

1993 "Labor Emigration and the Accumulation and Transfer of Human Capital," Asian and Pacific Migration Journal, 2(3):303-328.

UNDP

1995 Human Development Report, 1995. New York: Oxford University Press.

World Bank

1995a. Philippines: A Strategy to Fight Poverty Country Operations Division, Country Development I, East Asia and Pacific Region, Washington, D.C.

1995b. World Development Report, 1995. Washington, D.C. 